\title{
Fear of death in acute coronary syndromes - incidence and predictors
}

\section{Strach przed śmiercią w ostrych zespołach wieńcowych - częstość występowania i czynniki sprzyjające}

\author{
Agnieszka Sławska ${ }^{1}$, Zbigniew Siudak² \\ ${ }^{1}$ GVM Carint Sp. z o.o., Krakow, Poland \\ 2Department of Internal Medicine, Faculty of Medicine and Health Science, Jan Kochanowski University, Kielce, Poland \\ Head of the Department: Prof. Marianna Janion MD, PhD
}

Medical Studies/Studia Medyczne 2018; 34 (4): 304-308

DOI: https://doi.org/10.5114/ms.2018.80946

Key words: acute coronary syndromes, fear of death, dyspnoea.

Słowa kluczowe: ostre zespoły wieńcowe, strach przed śmiercią, duszność.

\begin{abstract}
Introduction: Fear of death is one of the symptoms of acute coronary syndrome (ACS). However, no large data describing the incidence and predictors to the occurrence of fear of death have been published so far.

Aim of the research: To investigate the prevalence of fear of death in patients with ACS as well as factors influencing its occurrence.

Material and methods: The sample consisted of 72 patients aged 38 to 92 years, who were hospitalised for ACS and treated with percutaneous coronary interventions (PCI) in an interventional cardiology centre. We used a dedicated, self-prepared, non-standardised questionnaire. Fear of death was defined as the simultaneous occurrence of a patient's fear and the thought of possible death.

Results: Fear of death was present in $25 \%$ of all enrolled patients. The independent predictors of fear of death occurrence in ACS were: severe or very severe pain (OR $=4.79 ; 95 \%$ CI: $1.44-15.95 ; p=0.011)$ and dyspnoea $(\mathrm{OR}=4.98$; $95 \%$ CI: 1.19-20.02; $p=0.027)$. There were no statistically significant differences in the occurrence of fear of death in pre-specified subgroups: gender, age, body mass index, co-morbidities, prior myocardial infarction, prior hospital stays, and presence of social support.

Conclusions: The majority of patients with ACS do not feel fear of death while hospitalised for interventional cardiology procedures. The incidence of fear of death may be influenced by the intensity of pain and presence of additional symptoms like dyspnoea.
\end{abstract}

\section{Streszczenie}

Wprowadzenie: Strach przed śmiercią jest jednym z objawów ostrego zespołu wieńcowego (OZW). Nie ma jednak dużych badań opisujących częstość występowania oraz czynniki sprzyjające pojawieniu się strachu przed śmiercią.

Cel pracy: Zbadanie częstości występowania strachu przed śmiercią u pacjentów z OZW, a także określenie, jakie czynniki wpływają na jego wystąpienie.

Materiał i metody: Grupa badana składała się z 72 kolejnych pacjentów w wieku 38-92 lat hospitalizowanych z powodu rozpoznanego OZW i leczonych metodą przezskórnej interwencji wieńcowej (PCI) na Oddziale Kardiologii Inwazyjnej w Ostrowcu Świętokrzyskim. Wystąpienie strachu przed śmiercią badano za pomocą niestandaryzowanej ankiety. Strach przed śmiercią zdefiniowano jako jednoczesne wystąpienie u pacjenta strachu oraz myśli o możliwej śmierci.

Wyniki: Śmierci bało się 25\% pacjentów z OZW. Niezależnymi czynnikami, które wpływały na poczucie strachu przed śmiercią, okazały się ból o dużym bądź bardzo dużym nasileniu (OR = 4,79; 95\% CI: 1,44-15,95; $p=0,011)$ oraz duszność $(\mathrm{OR}=4,98 ; 95 \%$ CI: 1,19-20,02; $p=0,027)$. Nie stwierdzono statystycznie istotnego związku między starchem przed śmiercią a płcią, wiekiem, wskaźnikiem masy ciała, chorobami współistniejącymi, przebytym zawałem serca, wcześniejszą hospitalizacją oraz wsparciem społecznym.

Wnioski: Większość pacjentów z rozpoznanym OZW nie odczuwa strachu przed śmiercią w trakcie OZW. Na pojawienie się strachu przed śmiercią mogą wpływać nasilenie bólu oraz występowanie dodatkowych objawów w postaci duszności. 


\section{Introduction}

Fear is defined as a normal reaction of an organism to danger, either real or imagined. Fear is one of the most basic emotions and is an adaptive aspect of development [1]

There are several factors that may cause fear in patients with acute coronary syndrome (ACS): biological and mental. Biological predictors include neurohormonal stress reaction, age, gender, hypoxia, and symptoms associated with ACS [1-9], whereas mental ones include: conditional modelling, personality type, and life experience [10, 11].

The level of fear of death in ACS patients is related to various factors. Their lack or presence affects the level of stress reaction. The modifying factors are: the extent of network support, behaviour of medical staff and patient's general knowledge [12-15].

Fear of death is often referred to as one of the main symptoms of ACS [16-19]; however, its magnitude and relevance are not fully determined. There is also scarce evidence on the predictors of fear of death in ACS patients.

\section{Aim of the research}

The aim of this study was to investigate the incidence of fear of death in patients with acute coronary syndromes and to analyse its prevalence in pre-specified subgroups.

\section{Material and methods}

The study was performed in Q3-Q4 2017 in the Department of Interventional Cardiology GVM Carint in Ostrowiec Świętokrzyski, Poland. The inclusion criteria were: hospital stay at the Department, age $>18$ years, ACS diagnosis (as initial diagnosis), and lack of co-morbidities that could influence fear perception: organic, mental disorders (dementia in Alzheimer's disease, vascular dementia, dementia in other diseases), schizophrenia, mood/affective disorders (manic episode, bipolar affective disorder, depressive episode), and neurotic disorders (anxiety disorders, phobias, obsessive-compulsive disorder), based on the assessment of patients' medical records and interviews. Informed consent for inclusion in the study was provided by all patients.

A survey method was used with a self-prepared, non-standardised questionnaire (including closed, open and half-open questions) filled in by the patient.

The questionnaire was performed at the earliest possible time when the patient's clinical status allowed it, which was in between 12 and $72 \mathrm{~h}$ of ward stay.

There were four parts of the questionnaire: (1) demographic data, personality traits, co-morbidities; (2) questions concerning fear, stress, death thoughts during cardiac syndromes; (3) hospital stay (current and past), social status; and (4) questions concerning the patient's clinical status.

Some of the questions in this non-standardised questionnaire in part 2 were inspired by Steptoe et al. [19]. The occurrence of fear of death was based on two questions: (1) I felt fear when cardiac symptoms occurred; (2) I thought I could die when symptoms occurred. Patients could answer both questions with: (0) not true; (1) slightly true; (2) partly true; (3) very true; (4) highly true.

As shown in Figure 1, patients were divided into two groups according to answers given to the two questions above and classified as either: fear of death (group 1) or no fear of death (group 0).

The following variables were assessed in both groups: age, gender, level of pain during ACS, additional symptoms, presence of social support, type of ACS, body mass index (BMI), co-morbidities, prior myocardial infarction (MI), and prior hospital stays.

The pain associated with ACS was assessed using a five-point scale: (0) no pain; (1) discomfort; (2) light pain; (3) moderate pain; (4) severe pain; (5) very severe pain. The five-point scale was inspired by Steptoe et al. [19].

The influence of additional symptoms associated with ACS on the study endpoint (fear of death) was also analysed. These included: (1) dyspnoea; (2) gastrointestinal symptoms; (3) fatigue; (4) sweating.

All baseline characteristics were tested including age, gender, diabetes mellitus, arterial hypertension, previous myocardial infarction, chronic kidney disease, lung diseases, place of residence, personality type (melancholy vs. others), similar stressful situation, intensity of pain (grade $\geq 4$ vs. others), dyspnoea, loneliness, lack of support, diagnosis of ST-elevation myocardial infarction (STEMI) (vs. other), and body mass index. Forward selection with a probability value for covariates to enter the model was set at the level 0.05 . Results were presented as odds ratios (OR) with 95\% confidence intervals (CI).

\section{Statistical analysis}

Continuous data were described using mean, median, minimum, maximum, standard deviation, and

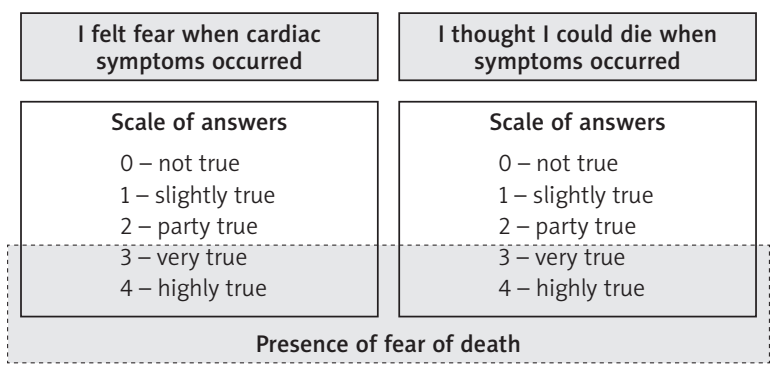

Figure 1. Fear of death - grouping variable 
Table 1. Baseline clinical characteristics with comparison between study groups

\begin{tabular}{|lccc|}
\hline Variable & Group 1 & Group 0 & $\boldsymbol{P}$-value \\
Age [year] & $68.4 \pm 12.9$ & $67.2 \pm 9.9$ & 0.677 \\
Gender (male) & $55.6 \%$ & $70.4 \%$ & 0.248 \\
Body weight $[\mathrm{kg}]$ & 83.4 & 79.9 & 0.329 \\
BMI & $28.8 \pm 3.1$ & $27.8 \pm 3.6$ & 0.292 \\
Diabetes & $27.8 \%$ & $22.2 \%$ & 0.631 \\
Hypertension & $59.3 \%$ & $66.7 \%$ & 0.577 \\
Type of ACS (STEMI) & $55.6 \%$ & $27.8 \%$ & 0.089 \\
\hline
\end{tabular}

$B M I$ - body mass index, ACS - acute coronary syndrome, STEMI ST-elevation myocardial infarction.

Table 2. The intensity of pain and occurrence of dyspnoea in acute coronary syndrome types

\begin{tabular}{|lccc|}
\hline Variable & Group 1 & Group 0 & $P$-value \\
STEMI $(n=25):$ & $n=10$ & $n=15$ & \\
\hline Pain & $3.8 \pm 0.9$ & $3.1 \pm 1.0$ & 0.083 \\
\hline Dyspnoea & $30.0 \%$ & $6.7 \%$ & 0.119 \\
NSTEMI $(n=25):$ & $n=5$ & $n=20$ & \\
\hline Pain & $2.6 \pm 1.7$ & $1.9 \pm 1.5$ & 0.328 \\
\hline Dyspnoea & $60.0 \%$ & $30.0 \%$ & 0.211 \\
UA $(n=22):$ & $n=3$ & $n=19$ & \\
\hline Pain & $2.7 \pm 1.5$ & $2.2 \pm 1.1$ & 0.491 \\
\hline Dyspnoea & $66.7 \%$ & $21.1 \%$ & 0.099 \\
\hline
\end{tabular}

STEMI - ST-elevation myocardial infarction, NSTEMI - non-ST-elevation myocardial infarction, UA - unstable angina.

Table 3. Variables independently influencing the occurrence of fear of death in acute coronary syndrome patients

\begin{tabular}{|lccc|}
\hline Variables & OR & $95 \% \mathrm{Cl}$ & $P$-value \\
Pain intensity $(\geq 4)$ & 4.79 & $1.44-15.95$ & 0.011 \\
Dyspnoea & 4.98 & $1.19-20.02$ & 0.027 \\
\hline
\end{tabular}

$O R$ - odds ratio, $\mathrm{Cl}$ - confidence interval.

quartiles. Normal distribution was confirmed by Kołmogorow-Smirnov test. Counts were presented as percentages. The differences between studied groups were assessed using $t$-tests and $\chi^{2}$ tests, depending on the variable. A multivariate stepwise logistic regression model was applied in order to identify independent predictors of fear of death in the study patients. Values of $p<0.05$ were considered statistically significant. Statistica ver. 12 (Tulsa, OK, USA) package was used for analysis.

\section{Results}

There were 72 patients enrolled in the study. Fear of death was present in $25 \%$ of all enrolled patients during ACS. Patients aged 38 to 92 years were enrolled in the study. Detailed information on the demographics is presented in Table 1.

Mean pain level during ACS was assessed by patients as $3.28 \pm 1.32$ in group 1 and $2.29 \pm 1.31$ in group $0(p=0.008)$. Pain level assessed by patients as sever or very severe was present in $55.6 \%$ of cases in group 1 and $20.4 \%$ in group $0(p=0.004)$.

A relationship between the presence of additional symptoms of ACS and fear of death was noticed (presence of other symptoms: $83.3 \%$ in group 1 and $50.0 \%$ in group $0, p=0.013$ ). Additional information on the pain intensity and dyspnoea occurrence in ACS types is presented in Table 2.

One of these symptoms - dyspnoea - was more frequent in group 1 (group 1: $44.4 \%$ vs. group 0: $20.4 \%, p=0.045$ ), similarly to gastrointestinal disorders (group 1: $38.9 \%$ vs. group 0: $16.7 \%, p=0.05$ ) accompanying ACS.

There was no relationship between the occurrence of fear of death and BMI, prior MI, co-morbidities, prior hospital stays, or social support.

The study revealed a relationship between the type of ACS and the occurrence of fear of death. In patients with fear of death STEMI was more frequently diagnosed (group 1: $55.6 \%$ vs. group 0: $27.8 \%, p=0.032$ ).

Independent predictors with an influence on the occurrence of fear of death are presented in Table 3.

\section{Discussion}

Fear is often described as a typical symptom of ACS [16-21].

Our study found that fear of death is only present in a minority of ACS patients, which is in line with some previous studies [17]. It seems that in the era of primary percutaneous coronary interventions (PCI) availability in Poland and constant education with shorter time delays, especially in STEMI patients, the fear of death is relatively rare in such patients, depending largely on the presence of severe pain or additional symptoms.

We found no relationship between fear of death with age and gender, as in the MEDEA study [18], but it is in contradiction to one study in which women reported fear of death more frequently [17].

As in previous studies, a relationship between the level of thoracic pain in ACS and fear of death was confirmed in our study [17-19].

Fear of death may be exaggerated if symptoms other than thoracic pain appear [18]. Dyspnoea or gastrointestinal symptoms may lead to disorientation, fatigue and intensification of fear in the situation of ACS $[3,4]$. It has been proven that accompanying clinical 
manifestations of a disease are the ones that patients fear more [22].

No association between social support and fear of death was found; however, no such data has been published so far.

Vega-Torres et al. revealed a relationship between fat diet and presence of fear in rats [23]. However, there are no studies available that confirm a relationship between obesity and fear in humans. In our study, there was no relationship between BMI and occurrence of fear.

According to Chandramouli et al., good health status is a common feature in people who do not feel fear of death. On the other hand, individuals suffering from chronic disease are more likely to fear death [24]. Our study has not proven this relationship because no such association was found in subgroups of patients with prior MI, co-morbidities, and prior hospital stays.

Finally, the occurrence of fear of death is related to the type of ACS that is STEMI, which has the highest frequency of patients with fear of death [18], whereas no such relation for non-ST elevation myocardial infarction (NSTEMI) or unstable angina (UA) was found $[17,19]$.

After performance of multivariate analysis the only significant variables influencing the occurrence of fear of death were: intensity of pain and presence of additional symptoms like dyspnoea.

The number of patients enrolled was small, and the study was performed in a single centre. We used a self-prepared, non-standardised questionnaire. The questionnaire did not gather more extensive data on variables that could potentially influence the occurrence of fear of death. It is also worth noting that the results present subjective feelings of patients and could not be objectively measured.

\section{Conclusions}

The majority of patients with ACS do not feel fear of death while hospitalised for interventional cardiology procedures. The incidence of fear of death may be influenced by the intensity of the pain or the presence of additional symptoms like dyspnoea.

\section{Conflict of interest}

The authors declare no conflict of interest.

\section{References}

1. Gullone E. The development of normal fear: a century of research. Clin Psychol Rev 2000; 20: 429-51.

2. Landowski J. Neurobiologia reakcji stresowej. Neuropsychiatr Neuropsychol 2007; 2: 26-36.

3. Müller P. Niedotlenienie w okresie pooperacyjnym. Anestezjol Intens Ter 2007; 3: 186-9.

4. Batura-Gabryel H. Lęk i depresja w krańcowych stadiach przewlekłej obturacyjnej choroby płuc. Przew Lek 2008; 2: 87-8.
5. Carstensen LL, Fung HH, Chalres ST. Socioemotional selectivity. Theory and the regulation of emotion in the second half of life. Motivation Emotion 2003; 27: 103-23.

6. Strelau J. Od teorii regulacji Tadeusza Tomaszewskiego do regulacyjnej teorii temperamentu. In: Psychologia Czynności - Nowe perspektywy. Kurcz I, Kądzielawa D (eds.). Scholar, Warsaw 2002; 34-45.

7. Szymura B, Waluszko A, Stachów D. Neurotyzm i lęk jako determinanty przebiegu procesów przetwarzania informacji. Przegl Psychol 2003; 46: 197-208.

8. Hajduk A, Korzonek M, Przybycień K, Ertmański S, Stolarek J. Badanie nasilenia lęku Testem CD Spielbergera u pacjentów z zaburzeniami rytmu serca. Ann Acad Med Stetin 2009; 55: 48-51.

9. Cepuch G, Wordliczek J. Ocena zależności pomiędzy natężeniem bólu a występowaniem lęku i depresji u młodych pacjentów hospitalizowanych z powodu choroby nowotworowej i reumatycznej. Pol Med Paliat 2006; 5: 44-53.

10. Fajkowska M, Krejtz I. Właściwości indywidualne i efekt twarzy w tłumie. Przegl Psychol 2007; 50: 401-31.

11. Bąbel P, Ziółkowska AM. Terapia behawioralna zaburzeń lękowych. Postep Psychiatr Neurol 2014; 23: 3-9.

12. Hebel K, Bieniaszewski L. Wsparcie społeczne i pomoc instytucjonalna dla osób niepełnosprawnych po udarze mózgu. Forum Med Rodz 2008; 2: 76-83.

13. Kózka M. Wsparcie społeczne w chorobie. In: Modele Opieki Pielęgniarskiej Nad Chorym Dorosłym: Podręcznik Dla Studiów Medycznych. Kózka M, PłaszewskaŻywko L (eds.). Wydawnictwo Lekarskie PZWL, Warsaw 2010; 45-9.

14. Kaźmierczak A. Wpływ komunikacji z personelem medycznym na doświadczanie choroby przez pacjentów. Homo Communicativus 2011; 1: 21-37.

15. Walewska E. Okres okołooperacyjny. In: Podstawy Pielęgniarstwa Chirurgicznego. Walewska E (ed.). Wydawnictwo Lekarskie PZWL, Warsaw 2006; 106-31.

16. Kirchberger I, Heier M, Kuch B, von Scheidt W, Meisinger C. Presenting symptoms of myocardial Infraction predict short- and long-term mortality: the MONICA/ KORA Myocardial Infraction Registry. Am Heart J 2012; 164: 856-61.

17. Whitehead DL, Strike P, Perkins-Porras L, Steptoe A. Frequency of distress and fear of dying during acute coronary syndromes and consequences for adaptation. Am J Cardiol 2005; 96: 1512-6.

18. Albarqouni L, von Eisenhart Rothe A, Ronel J, Meinertz T, Ladwig KH. Frequency and covariates of fear of death during myocardial infarction and its impact on prehospital delay: findings from the multicentre MEDEA Study. Clin Res Cardiol 2016; 105: 135-44.

19. Steptoe A, Molloy GJ, Messerli-Bürgy N, Wikman A, Randall G, Perkins-Porras L, Kaski JC. Fear of dying and inflammation following acute coronary syndrome. Eur Heart J 2011; 32: 2405-11.

20. Szyguła-Jurkiewicz B, Szymik M, Mrozowska B, Schmidt B, Michalak A. Psychologiczne uwarunkowania i konsekwencje ostrego zawału serca. Leki psychotropowe u chorych po ostrym zawale serca. Choroby Serca Naczyń 2011; 8: 62-9.

21. Hałaczkiewicz A, Tomaszewska M, Negrusz-Kawecka M, Mazurek W. Płeć a objawy ostrych zespołów wieńcowych - czy objawy kliniczne ostrych zespołów wieńcowych 
u kobiet są inne niż u mężczyzn? Adv Clin Exp Med 2007; 16: 457-63.

22. Kowalewska B, Krajewska-Kułak E, Ortman E, Gołębiewska A. Rola czynników psychicznych w rozwoju chorób. Probl Piel 2011; 19: 134-41.

23. Vega-Torres JD, Haddad E, Lee JB, Kalyan-Masih P, Maldonado George WI, López Pérez L, Piñero Vázquez DM, Arroyo Torres Y, Santiago Santana JM, Obenaus A, Figueroa JD. Exposure to an obesogenic diet during adolescence leads to abnormal maturation of neural and behavioral substrates underpinning fear and anxiety. Brain Behav Immun 2018; 70: 96-117.

24. Chandramouli B, Malathy S, Sarasa B, Amit A, Savitha R, Chandrasekaran K. "Thanatophobia": physician's perspective of dealing with patients with fear of death. J Nat Sci Biol Med 2018; 9: 103-04.

\section{Address for correspondence:}

Zbigniew Siudak MD, PhD

Department of Internal Medicine

Faculty of Medicine and Health Science

Jan Kochanowski University

al. IX Wieków Kielc 19, Kielce, Poland

Phone: +48 883992288

E-mail: zbigniew.siudak@gmail.com 